\title{
University choice: which attributes matter when you're paying the full price?
}

\author{
Caroline Walsh ${ }^{1}$, Jan Moorhouse ${ }^{2}$, Andrew Dunnett ${ }^{1}$, and Cornelius Barry ${ }^{1}$ \\ ${ }^{1}$ Claude Littner Business School, University of West London, London, UK \\ ${ }^{2}$ Hertfordshire Business School, University of Hertfordshire, Hatfield, UK \\ Corresponding author: Jan Moorhouse, Hertfordshire Business School, University of \\ Hertfordshire, De Havilland Campus, Mosquito Way, Hatfield, AL10 9EU, UK \\ j.moorhouse@herts.ac.uk
}

Key words: education, choice, youth, UK, conjoint analysis, longitudinal study, family

\begin{abstract}
This paper presents the results from a longitudinal study of students' choice of university in England. Students were surveyed initially when applying for university (Wave One) and then again when they were about to embark on their chosen course (Wave Two). The results from Wave Two demonstrated a high degree of consistency with the Wave One findings: course and university reputation are far more important and fees are relatively unimportant. However, a key result across both waves was that patterns of utility for students with no parental experience of university were significantly different from students whose parents had attended university. The utility associated with different levels of entry qualifications, of fees, and of university and course reputation, differed between social groups. The study suggests that the benefits of going to a highly rated university may be under-valued in families that have no direct experience of higher education. In addition, whilst females are more significantly put off by universities with low entry requirements, the qualitative attitudinal statements included in the follow-up study seem to indicate that so-called 'softer' factors may also influence their choice.
\end{abstract}




\section{Background}

In November 2010, the UK Government announced that tuition fees paid by undergraduates at English universities would rise from $£ 3,500$ per year to between $£ 6000$ and $£ 9000$ per year with effect from the academic year 2012-13. This increase in fees was viewed by many as controversial because of concerns for disadvantaged groups (referred to as "students from non-traditional backgrounds"). The change was only the latest move in a process of marketization in higher education that began in England in the 1990s, in which the burden of the cost of education was shifted from the tax payer to the individual student. Similar changes were taking place in other countries as governments attempted to cope with larger numbers of students entering higher education whilst protecting the standard of provision (Molesworth, Scullion et al. 2011).

In this study we examined student preferences using conjoint analysis, a technique used in commercial market research. The application of this technique enables the researcher to determine the mix of attributes that delivers the most utility for a given product or service. We conceptualised the student as a consumer of higher education and a higher education degree course as a complex, intangible one-off service, high in credence qualities. Although this methodology is controversial it should not be interpreted as a tacit endorsement (or condemnation) of the marketization of education. Our reason for conceptualising the student in this way is to gain insights into the behaviour of this newly formed group of consumers since it would seem that students increasingly see themselves in this way (Nordensvard in Molesworth, Scullion et al. 2011).

Whilst there are parallels between the choice of university course and other conventional consumption behaviours, there may be important differences. One difference is that students do not simply choose their university and their course. Rather they have to obtain the qualifications necessary to gain entrance into their chosen institution. Thus part of the choice-making process involves an assessment of which institution and course might accept them. A further complexity is that the choice decision for many purchases may be viewed as a discrete event whereas, in contrast, the choice and thereafter the consumption of a university degree programme takes place over an extended period of time during which the consumer is likely to undergo important changes in how they evaluate their experience. Therefore in addition to a point estimate of student preferences we wanted to explore changes over time in these preferences using a longitudinal research design. When the full study has been completed these preferences will have been examined at four stages: 1) prior to the choice of university when students are in the process of making applications; 2 ) when a definite choice of university and course has been made, and the student accepted at an institution having achieved the grades required; 3 ) during consumption (that is, while attending university); and 4) post consumption, once the students have completed their studies. This paper reports on the first two stages of the study.

Conjoint analysis is a well-established market research technique. It generates a simulated choice environment in which consumers are asked to indicate their preferred combinations (or packages) of product attributes. By presenting a number of such packages, the researcher can measure the importance of each attribute and the way in which consumers trade-off one attribute against 
another. In this way it is possible to identify an 'ideal' package that maximises the utility of any one group of consumers.

\section{Higher education: a highly involved decision and a complex service consumed over an extended period of time}

The literature on the marketing of services conceptualises a service such as higher education as highly complex and high in divergence (Shostack 1987). It is intangible, heterogeneous, inseparable and perishable (Zeithaml, Parasuraman et al. 1985), and difficult for the consumer to evaluate, even after purchase, because it is high in credence qualities and low in search qualities (Zeithaml 1981). Undergraduate higher education is a significant, usually one-off, purchase. It is a decision likely to affect not only the next three or four years, but will also influence long term future career prospects. Having chosen a university and a course, these elements are written into a graduate's CV, along with his or her results, and carried forward like an indelible brand attached to the individual. University choice is a complex, highly involved decision process (Zaichkowsky 1985), especially when, along with its future ramifications, there are also real and present risks for the student making a choice of university course. The risks may relate to i) performance, that is, whether the student will successfully complete the course and achieve a respectable grade; ii) social and psychological concerns relating to the experience of attending a particular institution, that is, friendship, personal contacts and the psychological impact of the learning experience; iii) time: university courses typically take three or even four years to complete; and now increasingly, iv) financial risks: the costs associated with university are considerable and may include: fees, living costs, and potential loss of earnings whilst studying (Mitra, Reiss et al. 1999).

However, the process of evaluation may have been made somewhat easier for today's prospective students by the plethora of external information available prior to purchase. This includes KIS (Key Information Set) data, league tables, university websites, comparison sites and forums.

Nevertheless, the credence quality of undergraduate education means that there remain problems for students in assessing whether they are getting a 'good' quality of service, notwithstanding the evidence available from the National Student Survey and student satisfaction scores (HESA 2011). These scores, along with university league tables, facilities, reputation (for university and course), word of mouth and fees may be used as cues or proxies for the unknowable quality of the education itself (Zeithaml, Parasuraman et al. 1985; Briggs and Wilson 2007).

A number of studies have examined what motivates prospective undergraduates to go to university (Chapman 1986; Foskett and Hemsley-Brown 2001; Bergerson 2009). Their findings suggest that university preference is affected by the culture, situation and beliefs of prospective students. Higher education choice needs to be seen in context, as both a complex and intangible service (Allen 2002; Moogan 2011) and also as a multi-layered decision process which has demographic, environmental, psychological and socially constructed influences (Allen 2002; Raposo and Alves 2007; Bergerson 2009; Moogan 2011).

In addition to the decision about whether to go to university the decision about which university to attend has also been investigated (Raposo and Alves 2007). Several studies have developed 
comprehensive university choice models, outlining various stages that potential undergraduates may go through. See especially the Hossler and Gallagher three stage model (Hossler and Gallagher 1987); Morgan's extension of the rational choice model (Morgan 2002), Perna's conceptual model of college choice (Perna 2006); Pitre's model (Pitre, Johnson et al. 2006) based on the Theory of Reasoned Action (Ajzen and Fishbein 1980) and also Tierney and Venegas' Cultural Framework model (Tierney and Venegas 2009). However Bergerson (2009) highlights that, in the $21^{\text {st }}$ century, the idea that students are homogenous and / or that one model can cover every situation has fallen out of favour. By acknowledging that university is also an emotional decision and highly reliant on experience, it has also been argued that prospective students who have parents or significant others with experience of university will find it easier to evaluate their university options (Maringe 2006; Clarke 2007; Bergerson 2009; Doolan 2010). The FLAG model framework used by Allen (2002) shows that regardless of the significant information processing and cognitive stages of decision-making that may exist, final selection of a university will often come down to whether or not it feels right i.e. 'Fits Like A Glove'. The complexity and the intangible nature of the higher education experience create additional pressure on the young student-consumer and add to the difficulty of making a wellinformed choice, let alone the 'right' choice.

\section{The factors that influence university choice}

Whilst potential undergraduates may be motivated by a multitude of factors, the focus of this study is the identification and evaluation of the factors (attributes) that prospective undergraduates value most when selecting a university. Bergerson (2009) cites a review by Paulsen (1990) of over 200 journal articles from the 1970s and 1980s in her re-examination of factors affecting college choice. Bergerson's review (2009) outlines a number of recurring institutional factors that students weigh up when making a choice. These include the following factors: location, course offerings, reputation, sense of fit, and social opportunities. In the US students pay fees for university and unlike England there is no upper or lower limit on fees. Bergerson (2009) suggests that financial considerations play a major part in students' post-secondary choices.

Soutar and Turner (2002) looked at students in Western Australia. The four most important determinants of their preferences for university were found to be: course suitability, academic reputation, job prospects and teaching quality. Earlier than this and in the UK, Hooley and Lynch (1981) examined university choice and identified six key factors, namely: course suitability, university location, academic reputation, distance from home, type of university (modern / old), and advice from parents and teachers. A variety of other studies (Brooks 2002; Pasternak 2005; Clarke 2007) highlight that, in addition to fees, attributes such as the reputation of the institution, the reputation of the course, course content, location, study modes, teaching staff, course information, facilities (e.g. libraries, online resources, rooms and equipment and extra-curricula facilities such as catering, sports facilities, and the Student Union) all play a part.

So it would appear that there are a few key attributes that are particularly influential in determining students' university choice. Furthermore, according to research by Bettman, Luce et al. (1998), 
individuals process in a more extensive, selective, and in a more attribute-based fashion when choices are more emotionally laden. In examining students' choice of university course it is worth bearing in mind that choosing a complex, high credence, one-off purchase is a difficult task for a consumer. This type of choice decision is a learning process (Levine 1998) during which a person's preferences may shift and evolve. Findings from the literature are summarised in Table 1, using matrices created by Raposo and Alves (2007) and Cubillo, Sanchez et al. (2006) and extended to include other studies.

INSERT APPENDIX 1: Table 1: Attributes of most influence in students' university preference.

\section{Research Objectives}

The study was designed to examine the following:-

1. What factors are most important in affecting students' choice of university and course?

2. Are patterns of utility significantly different for students from non-traditional backgrounds (that is, families where neither parent attended university) compared to students from families where at least one parent attended university?

3. Are patterns of utility significantly different for students from lower socio-economic groups compared to higher socio-economic groups?

4. Are patterns of utility significantly different for students educated in the state sector compared to those educated in fee paying schools?

5. Are patterns of utility significantly different for female students compared to male students?

Given the evolving nature of student preferences, and the long duration over which purchase and consumption take place, a longitudinal approach was adopted for the study. This paper reports the findings of the first two parts of the longitudinal study (known as Wave One and Wave Two). An earlier paper (Dunnett, Moorhouse et al. 2012) reported the results from Wave One.

\section{Method}

\section{The focus group}

A focus group was conducted at a state school in West London in July 2011. This school served a population made up of mainly lower income families and families where there was no pattern of participation in higher education. The focus group comprised eight male and female year 12 
students taking AS/A levels (16 or 17 year olds). This group would be applying for university in the following term for entry the following year (September 2012).

The results from the focus group supported the literature inasmuch as price was seen as a relatively less important criterion, even for a group of students predominantly from less well-off families. The most important attributes for the students in the focus group were university and course reputation, and location. In summary, the focus group provided nuanced insights into the evidence from the literature review. Taken together these sources enabled us to design a parsimonious specification for our conjoint analysis.

\section{Conjoint Analysis - Wave One}

'Wave One' was based on the responses of 400 people who completed an on-line questionnaire. The questionnaire was hosted by a market research organisation that had access to a specialist 'panel provider" Opinionpanel.co.uk which is "the independent market research agency dedicated to understanding students before, during and after their time at university" (OpinionPanel 2013). This agency is nationally recognised and used by the UK government and by HEFCE for their own higher education research purposes. Our research accessed the subset then known as the Future Panel (subsequently renamed the Applicant Panel) which consisted of some 24,000 young people all of whom were planning to begin a full time undergraduate course at a university in 2012. Almost all of these were 17 or 18 years old at the time of the survey.

Such panels consist of people who sign up to complete on-line questionnaires. The respondents are 'incentivised' - usually by a small non-monetary reward such as vouchers for each completed questionnaire. For this study some demographic characteristics of the sample were set in advance, and quotas set accordingly. Thus, because of these quotas, the number of people who applied to complete the questionnaire was far in excess of the 400 who were accepted.

The characteristics of the sample predetermined by the quotas were:

- Gender: 200 female, 200 male

- Geographical location - the numbers in our sample were proportional to the numbers in each of the fourteen commercial television regions. The use of ITV regions for stratified sampling is common practice in market research.

- Social class: $200 \mathrm{ABC1}, 200 \mathrm{C2DE}$ - social class was determined by parents' occupation using standard social grade definitions $A, B, C 1, C 2, D$ and $E$ where $A$ and $B$ refer to higher and middle managerial, administrative or professional occupations, $C 1$ refers to junior managerial, administrative or professional occupations, C2 covers skilled working class occupations, D semi and unskilled occupations, and E covers the lowest paid and those dependent on state benefits. The software automatically codes a given occupation as either $A B C 1$ or $C 2 D E$.

The other demographic characteristics of the sample were as follows:- 
- Educational background of parents (based on the question: Did your parents go to university?) Neither parent went to university (55\%); mother went to university (12\%); father went to university (13\%); both parents went to university (20\%)

- Fee-paying or state school - about $10 \%$ of the sample came from fee-paying schools, the remainder from the state sector. This proportion (and that for socio-economic groups) is broadly in line with the proportion in the population as a whole (Department for Education, 2014)

\section{Conjoint Analysis - Wave Two}

In 'Wave Two' the original 400 respondents were contacted again and asked if they would participate in a follow-up study. 272 of the original 400 completed the questionnaire for Wave Two (a 68\% response rate). The key demographic characteristics of the 272 students in Wave Two were comparable to those for Wave One, except for a slight bias towards female respondents. The characteristics of the two samples are shown in Table 2 in Appendix 2.

INSERT APPENDIX 2

Conjoint Analysis - the technique

Conjoint analysis is a statistical technique used in market research to determine the importance that consumers attach to various features (or attributes) of a good or service. It does this by offering respondents a controlled set of potential products or services. By analysing the choices they make the implicit valuation of the individual elements making up the good or services can be calculated. These implicit valuations are known as utilities or part-worths (for a non-technical explanation see Hauser (n.d.)).

In our research we looked at six attributes, shown in column 1 of table 3 in Appendix 3. These attributes are derived from the results of the focus group and from the extant literature discussed above.

\section{INSERT APPENDIX 3}

For the first two attributes there are three 'levels' (high, average, low) and our hypothesis is that a higher reputation would be associated with more utility. Entry qualifications and fees also have three levels but here a higher level of the attributes should lead to less utility. So for example it would seem rational to choose a university with a high reputation, a high course reputation but with low entry qualifications and low fees. The fifth attribute (university orientation) does not have levels and there is no reason to suppose that any one of the three types of university provides more or less utility than any other. Similarly for the last attribute there is no a priori reason to suppose that a local university provides more utility than a non-local one. Ultimately however these are all 
conjectures about what represents 'rational' behaviour. The whole point of conjoint analysis is to 'let the data decide'.

In both Wave One and Wave Two of the study each respondent answered ten questions. Each question asked the respondent to choose one of three competing products. Table 4 in Appendix 4 provides an example of the format of the question.

\section{INSERT APPENDIX 4}

There were 10 sets of ten questions (so 400/10 $=40$ respondents were presented with each of the ten sets). Each set presented the attributes in a different order, all of this 'rotation' being done to minimise bias. For each of the 400 respondents this produces information on preferences.

In the Wave Two study each respondent (drawn from the same 400 individuals who completed the Wave One questions) again answered ten questions. Each question asked the respondent to choose one of three competing university packages (see Appendix 4). As in Wave One each set of questions presented the choices (and the attributes within the choices) in a different order, so as to minimise bias. Of the original 400 respondents 272 completed the Wave Two questions. For each of the 272 respondents this produced information on preferences and these are analysed and compared with the original results from the Wave One conjoint analysis.

\section{Analysis of Wave One and Wave Two Results}

\section{What factors are most important in affecting students' choice of university and course?}

The relative importance of attributes is shown in Table 5 Appendix 5 (left hand side). It seems that by far the most important factors (both in Wave One and Wave Two) are course reputation and university reputation. Together these two factors account for almost 60 per cent of people's preference for a university. The top four factors remain consistent between Wave One and Wave Two. These results are displayed in a box and whisker format in Figure 1 in Appendix 6.

\section{INSERT APPENDIX 5}

\section{INSERT APPENDIX 6}

Table 5 Appendix 5 (right hand side) also shows how utility changes as one moves from a low to a high level of each attribute. These are displayed as zero centred differences (ZCDs) and the difference between a low level and a high level of any particular attribute is an indication of the importance of that attribute. Thus for example in Wave 1 a course with a low reputation reduces utility by 106 but a high reputation increases utility by 81 .

It is possible to compare Wave One with Wave Two by looking at importances and at ZCDs. It is clear that in Wave Two fees become much less important and entry qualifications become much more 
important. Note however that in Wave Two a low level for entry qualifications is now associated with a loss of utility rather than a gain.

These results are displayed in Figures 2 and 3 (Appendices 7 and 8)

INSERT APPENDIX 7

INSERT APPENDIX 8

\section{Students whose parents did not attend university}

Our second research question relates to the effect of parental influence. We used independent samples t-tests to compare those respondents whose parents went to university with those respondents whose parents had no such experience. We also compared the results across Wave One and Wave Two. The results (zero centred differences) are shown in Table 6 in Appendix 9 and in Figure 4 Appendix 10 which shows the effect of university reputation on utility for the two groups. The Figure shows the change in utility experienced by students whose parents went to university (the solid red line) compared to the change in utility experienced by students where neither parent went to university (the dotted line). University reputation has more impact on students whose parents went to university - a high reputation confers a bigger increase in utility and a low reputation a greater loss of utility than it does for students where neither parent went to university. As Table 6 shows the difference between the two groups - or market segments - is statistically significant in Wave 2 (as shown by the asterisks in the final column)

The fact that respondents whose parents did not go to university gain significantly less utility from a university with a high reputation and are less 'put off' by a university with a low reputation could reflect a difference in their social/cultural capital and their lower expectations as less experienced consumers of this complex credence service. (Mitra, Reiss et al. 1999; Allen 2002).

\section{INSERT APPENDIX 9}

INSERT APPENDIX 10

When we consider attitudes to course reputation the Wave Two results show that there is no longer a significant difference between students whose parents went to university and the rest. Similarly attitudes towards fees do not differ significantly between the two groups in Wave Two.

The attitude towards entry qualifications is more complex. In Wave Two the difference in attitudes between the two groups is less marked than in Wave One but there is still a significant difference in attitude towards average and high fees - respondents whose parents did not attend university suffer more disutility from high entry qualifications. Such students also enjoy more positive utility from medium entry qualifications. On the other hand, there is no longer a significant difference in attitude towards low entry qualifications. In fact in Wave Two both groups now associate low entry 
qualifications with a loss of utility rather than a gain as they did in Wave One. It seems that having made a choice of university, low entry qualifications are seen by both segments as a proxy for low quality. This has echoes of Groucho Marx's famous line: "I refuse to join any club that would have me as a member." (Robertson 1996 :326). The motivation would now seem to be: if it's easy to get in to a particular institution it can't be worth going to.

\section{Students from lower socio-economic groups}

The results split by socio-economic group are shown in Table 7 in Appendix 11. There is a smaller but still significant difference between the two groups in their attitude towards university reputation. For both groups university reputation is important, but for $A B C 1 \mathrm{~s}$ it is more important to be going to a good university. In Wave Two, unlike Wave One, there is also a significant difference between the two groups in their attitude to fees. The C2DEs display a marked preference for lower fees over higher fees. The $A B C 1 s$ are perhaps more confident that parents can or will support them or they have less fear of the loan debt. The analysis also indicates a significant difference between ABC1s and C2DEs in the levels of utility associated with distance (local versus non-local). C2DEs have a stronger preference for a local (and therefore cheaper) university, which might indicate that students from lower socio-economic groups are more likely to stay at home when studying. The difference in attitudes to fees and distance certainly seem to imply some 'cost consciousness' and additional price sensitivity for students from lower socio-economic groups when faced with the reality of going to university.

INSERT APPENDIX 11

\section{Gender differences}

The effect of gender on utility is shown in Table 8 in Appendix 12. In Wave Two there are no significant differences between males and females in their attitudes towards course or university reputation, orientation, distance or fees. There is a significant difference with regards to entry qualifications. Females see more benefit than males in medium entry qualifications but relative to males they now associate low entry qualifications with significantly more disutility. Both genders now view low entry qualifications in a negative light.

INSERT APPENDIX 12

\section{Qualitative insights into the reasons given by students for their actual choice of university}

In Wave Two, in addition to the conjoint analysis on university choice, students were also asked to state which university they were about to enter and to write statements in answer to the question, 
'Why did you choose this university?' We conducted a simple content analysis of these statements paying particular attention to the key themes of i) university reputation, ii) course appeal, iii) location/convenience, iv) teaching and facilities v) fees and iv) FLAG variables - these are the emotional concerns related to fitting in (Allen 2002). At this point the respondents had chosen and been accepted into a university, so we were able to cross tabulate the responses against actual university destinations: tier 1 (Russell Group), tier 2 (1960s institutions) and tier 3 post-1992 universities. We also cross tabulated the results by gender and by whether parents went to university.

Students who had been accepted into a Russell Group university seemed to be more likely to state that a good ranking and/or a high reputation was an important factor in their choice. Institutions with a 'good' range of courses were also more highly valued by these students. They were also much less concerned with achievable entry grades than other groups, and they were less concerned about fee rates than the students who had been accepted into post-1992 institutions. For students about to enter these 'new' universities it was particularly important that they liked the location and city area. However what these students saw at the open day was less influential than it was for students in the other groups. Across all groups FLAG factors were important.

With tier 3 students (post-1992 institutions) there did seem to be an indication that FLAG components were important to female students. Female students were also more likely to refer to the university's ability to 'meet their needs', to 'liking the atmosphere' of the university, and to 'feeling comfortable' at the university

There does seem to be some indication that FLAG factors (fitting in) are more important for students where neither parent attended university, specifically compared with students from families where both students attended university.

\section{Conclusion}

This paper reports the results from Wave One and Wave Two of a study that explores the impact of changes in the funding of higher education on the preferences and utilities of students who chose a university in 2012. It attempts to determine whether the value placed on a university education varies across different groups - for example, are the preferences and utilities of non-traditional students significantly different from those of more traditional students, as indicated by socioeconomic group and parents' university education? Conjoint analysis was used to explore the importance associated with various attributes and the change in utility that resulted from changing the levels of these attributes. The results may be summarised as follows:

\section{Patterns of utility for students with no family experience of university (that is, families where neither parent attended university) compared to students from families where at least one parent attended university: The results from Wave One and from Wave Two revealed marked differences between the two groups in terms of utility associated with entry qualifications and university reputation. Students whose parents had no experience of university were less 'put off' by lower}


reputation and more deterred by high entry qualifications, suggesting that family history of university life is an important factor affecting the choice of university .

Patterns of utility for students from lower socio-economic groups compared to higher socioeconomic groups: Although the results from Wave One were not significant, Wave Two of the study found significant differences in utility related to university reputation, with C2DEs less deterred by a university with a lower reputation. There was also a clear preference for lower fees and also a local university amongst lower socio-economic groups.

Patterns of utility for female students compared to male students: The Wave Two study found that girls derive more disutility from universities with lower entry qualifications.

The results from Wave One and Wave Two of the longitudinal study confirm that course and university reputation are by far the most important factors influencing students' choice of university despite the rise in fees and irrespective of students' background. Fees remain a relatively unimportant determinant of the overall utility associated with a university. However, a key finding of the study was that students from lower socio-economic groups experience a higher loss of utility as a result of higher fees. Additionally students whose parents did not attend university suffer a smaller loss of utility from a university with low reputation but also gain less from a university with a high reputation. Moreover it would appear that non-traditional students are more likely to be put off by high prices and more likely to accept or 'settle' for a university with a lower reputation and lower entry criteria.

The benefits of going to a highly rated university may be under-valued in families that have no direct experience of higher education and so, when faced with a choice, children from these families may decide that less prestigious universities are right for them. This is consistent with findings by UCAS (Hawdon 2012) and others (James 2000; Pasternak 2005). Whilst females are more significantly put off by universities with low entry requirements, the qualitative attitudinal statements seem to indicate that so-called 'softer' factors may also influence their choice. Whilst the factors that are most important are common to all groups, underlying patterns of utility reveal some cause for concern with regards to inclusiveness, perhaps not in terms of raw numbers going into higher education, but in terms of the likely participation at elite universities from non-traditional social groups.

From a micromarketing perspective this study provides evidence that may assist university management in its decisions about the selection (for the elite universities) or recruitment (for the post-1992 institutions) of students. More importantly perhaps, from a macromarketing perspective the research provides a nuanced account of the factors that affect students' choice of university that may inform government policy towards Higher Education.

\section{Future direction for research}

We plan to carry out follow-up studies to track shifts in preferences during and beyond the students' experience of their higher education choice. A key methodological issue to address will be the size of the samples for the subsequent studies. The research started out with a high quality sample of 400 
respondents. In Wave 2 this declined to 272 , a response rate of $68 \%$ from the original 400 . If a similar response rate is achieved in Waves 3 and 4 the samples will decline to 185 and 126 respectively. Samples this small will limit the analysis that can be carried out on the data but we plan to explore options to ensure larger samples for Wave 3 and Wave 4.

\section{Appendices}

Appendix 1 Table 1: Attributes of most influence in students' university preference

Appendix 2 Table 2: Sample characteristics for Wave One and Wave Two

Appendix 3 Table 3: University attributes used in the conjoint analysis study for Wave One and Wave Two

Appendix 4 Table 4: Conjoint question format example

Appendix 5 Table 5: Relative importance of attributes

Appendix 6 Figure 1: Box and whisker plots for Wave One and Wave Two

Appendix 7 Figure 2: Change in importance of fees from Wave One to Wave Two

Appendix 8 Figure 3: Changes in importance of entry qualifications from Wave One to Wave Two

Appendix 9 Table 6: Comparison of factors by 'whether parents went to university'

Appendix 10 Figure 4: Parental influence on attitude to university reputation

Appendix 11 Table 7: Social class comparisons

Appendix 12 Table 8: Gender effects on attribute utility 


\section{Appendix 1}

\begin{tabular}{|c|c|c|c|c|c|c|c|c|c|c|c|}
\hline $\begin{array}{l}\text { Table 1: Attributes of } \\
\text { most influence in } \\
\text { students' university } \\
\text { preference. }\end{array}$ & $\begin{array}{l}\text { University } \\
\text { Reputation } \\
\text { / Image }\end{array}$ & $\begin{array}{l}\text { Course } \\
\text { Reputation }\end{array}$ & $\begin{array}{l}\text { Course } \\
\text { Suitability } \\
\text { / Range }\end{array}$ & $\begin{array}{l}\text { Career / } \\
\text { Prospects }\end{array}$ & $\begin{array}{l}\text { Teaching / } \\
\text { Faculty } \\
\text { Quality }\end{array}$ & $\begin{array}{l}\text { Location / } \\
\text { Proximity }\end{array}$ & $\begin{array}{l}\text { Fees / } \\
\text { Costs }\end{array}$ & Facilities & $\begin{array}{l}\text { Entry } \\
\text { Grades }\end{array}$ & $\begin{array}{c}\text { Research } \\
\text { Quality }\end{array}$ & Other \\
\hline $\begin{array}{l}\text { Hooley and Lynch } \\
\text { (1981) in Soutar and } \\
\text { Turner (2002) }\end{array}$ & $\checkmark$ & & $\checkmark$ & & & $\checkmark \checkmark$ & & & & & $\begin{array}{l}\text { Type of university old / } \\
\text { modern } \\
\text { Advice from parents / } \\
\text { teachers }\end{array}$ \\
\hline $\begin{array}{l}\text { Murphy (1981) } \\
\text { in Raposo and Alves } \\
\text { (2007) }\end{array}$ & $\checkmark$ & & & & & & $\checkmark$ & & & & $\begin{array}{l}\text { Influence of brothers \& } \\
\text { friends }\end{array}$ \\
\hline $\begin{array}{l}\text { Webb (1993) } \\
\text { in Raposo and Alves } \\
\text { (2007) }\end{array}$ & $\checkmark$ & & & $\checkmark$ & & $\checkmark$ & $\checkmark$ & & & & Accreditations \\
\hline $\begin{array}{l}\text { Chapman (1993) } \\
\text { in Raposo and Alves } \\
\text { (2007) }\end{array}$ & $\checkmark$ & $\checkmark$ & & & $\checkmark$ & & & & & & \\
\hline $\begin{array}{l}\text { Coccari and Javalgi } \\
\text { (1995) } \\
\text { in Raposo and Alves } \\
(2007)\end{array}$ & & $\checkmark$ & $\checkmark$ & & $\checkmark$ & & $\checkmark$ & & & & Classroom instruction \\
\hline $\begin{array}{l}\text { Kallio (1995) } \\
\text { in Raposo and Alves } \\
(2007)\end{array}$ & $\checkmark$ & & $\checkmark$ & & & & & $\checkmark$ & & & $\begin{array}{l}\text { Size of institution } \\
\text { financial aid }\end{array}$ \\
\hline $\begin{array}{l}\text { Qureshi (1995) in } \\
\text { Cubillo, Sanchez et al. } \\
\text { (2006) }\end{array}$ & $\checkmark$ & $\checkmark$ & $\checkmark$ & & & & $\checkmark$ & & & & Availability of financial aid \\
\hline $\begin{array}{l}\text { Lin (1997) in Soutar } \\
\text { and Turner (2002); } \\
\text { Raposo and Alves } \\
\text { (2007) }\end{array}$ & $\checkmark$ & & & $\checkmark$ & $\checkmark$ & & $\checkmark$ & $\checkmark$ & & & $\begin{array}{l}\text { International } \\
\text { student life } \\
\text { internship opportunities }\end{array}$ \\
\hline
\end{tabular}




\begin{tabular}{|c|c|c|c|c|c|c|c|c|c|c|c|}
\hline $\begin{array}{l}\text { Table 1: Attributes of } \\
\text { most influence in } \\
\text { students' university } \\
\text { preference. }\end{array}$ & $\begin{array}{l}\text { University } \\
\text { Reputation } \\
\text { / Image }\end{array}$ & $\begin{array}{c}\text { Course } \\
\text { Reputation }\end{array}$ & $\begin{array}{l}\text { Course } \\
\text { Suitability } \\
\text { / Range }\end{array}$ & $\begin{array}{l}\text { Career / } \\
\text { Prospects }\end{array}$ & $\begin{array}{l}\text { Teaching / } \\
\text { Faculty } \\
\text { Quality }\end{array}$ & $\begin{array}{l}\text { Location / } \\
\text { Proximity }\end{array}$ & $\begin{array}{l}\text { Fees / } \\
\text { Costs }\end{array}$ & Facilities & $\begin{array}{l}\text { Entry } \\
\text { Grades }\end{array}$ & $\begin{array}{l}\text { Research } \\
\text { Quality }\end{array}$ & Other \\
\hline $\begin{array}{l}\text { Turner (1998) in } \\
\text { Soutar and Turner } \\
\text { (2002) }\end{array}$ & $\checkmark$ & & & $\checkmark$ & $\checkmark$ & & & $\checkmark$ & & & $\begin{array}{l}\text { Qualifications valued by } \\
\text { employers }\end{array}$ \\
\hline $\begin{array}{l}\text { Ivy (2006)in Cubillo, } \\
\text { Sanchez et al. (2006) }\end{array}$ & & & $\checkmark$ & & $\checkmark \checkmark$ & & & & & $\checkmark$ & \\
\hline $\begin{array}{l}\text { Donnellan (2002) } \\
\text { in Raposo and Alves } \\
\text { (2007) }\end{array}$ & & & $\checkmark$ & & & $\checkmark$ & & & & & $\begin{array}{l}\text { Personal contacts } \\
\text { influence of parents } \\
\text { social life }\end{array}$ \\
\hline $\begin{array}{l}\text { Soutar and Turner } \\
\text { (2002) }\end{array}$ & $\checkmark$ & & $\checkmark$ & $\checkmark$ & $\checkmark$ & $\checkmark$ & & & & & $\begin{array}{l}\text { Favoured by family } \\
\text { campus atmosphere }\end{array}$ \\
\hline $\begin{array}{l}\text { Price, Matzdorf et al. } \\
\text { (2003) in Cubillo, } \\
\text { Sanchez et al. (2006) }\end{array}$ & & & $\checkmark$ & & $\checkmark$ & & & $\checkmark$ & & & $\begin{array}{l}\text { Availability of quiet areas } \\
\& \text { computers }\end{array}$ \\
\hline $\begin{array}{l}\text { Shanka, Quintal et al. } \\
\text { (2005) in Raposo and } \\
\text { Alves (2007) }\end{array}$ & & & & & $\checkmark$ & $\checkmark$ & $\checkmark$ & & & & $\begin{array}{l}\text { Friends study } \\
\text { family recommend } \\
\text { safety }\end{array}$ \\
\hline $\begin{array}{l}\text { Holdswoth and Nind } \\
\text { (2005) in Raposo and } \\
\text { Alves (2007) }\end{array}$ & & $\checkmark$ & $\checkmark$ & $\checkmark$ & & $\checkmark$ & $\checkmark$ & & & & $\begin{array}{l}\text { Availability of } \\
\text { accommodation }\end{array}$ \\
\hline Yamamoto (2006) & $\checkmark$ & & & $\checkmark$ & $\checkmark$ & & & $\checkmark$ & & & $\begin{array}{l}\text { Campus and social } \\
\text { scholarship }\end{array}$ \\
\hline $\begin{array}{l}\text { Raposo and Alves } \\
\text { (2007) }\end{array}$ & $\checkmark$ & & & $\checkmark$ & & $\checkmark$ & $\checkmark$ & $\checkmark$ & & & $\begin{array}{l}\text { Level of university } \\
\text { promotion } \\
\text { Help getting first job }\end{array}$ \\
\hline
\end{tabular}




\section{Appendix 2}

Table 2: Sample characteristics for Wave One and Wave Two conjoint analyses

\begin{tabular}{|l|l|l|l|}
\hline & & $\begin{array}{l}\text { Wave One }(\mathrm{n}=400) \\
\text { percent }\end{array}$ & $\begin{array}{l}\text { Wave Two (n=272) } \\
\text { percent }\end{array}$ \\
\hline Social class & ABC1 & 50 & 51 \\
\hline & C2DE & 50 & 49 \\
\hline Parents went to university? & neither & 55 & 56 \\
\hline & One or both & 45 & 44 \\
\hline Educational background & state & 90 & 90 \\
\hline & private & 10 & 10 \\
\hline Gender & Male & 50 & 44 \\
\hline & female & 50 & 56 \\
\hline
\end{tabular}

\section{Appendix 3}

Table 3: University attributes used in the conjoint analysis study (Wave 1 and Wave 2)

\begin{tabular}{|l|l|l|l|}
\hline University reputation & High & Average & Low \\
\hline Course reputation & High & Average & Low \\
\hline Entry qualifications & Low (200 points) & Medium (260 points) & High (340 points) \\
\hline Fees per annum & $\mathrm{f6000}$ & $\mathrm{f7500}$ & $\mathrm{f} 9000$ \\
\hline University orientation & Industry focussed & Research focussed & Teaching focussed \\
\hline Distance from home & Local & Not local & \\
\hline
\end{tabular}




\section{Appendix 4}

Table 4: Conjoint question format example.

Please choose the most appealing option from the following product choices

\begin{tabular}{|l|l|l|l|}
\cline { 2 - 4 } \multicolumn{1}{l|}{} & Choice $\mathbf{P}$ & Choice Q & Choice R \\
\hline University Orientation & Research focused & Teaching focused & Industry focused \\
\hline University Reputation & Average & High & Low \\
\hline Course Reputation & Average & Low & High \\
\hline Distance from home & Not local & Local & Local \\
\hline Entry Qualifications & Medium (260 points) & Low (200 points) & High (340 points) \\
\hline Fees & f6000 per year & f9000 per year & $£ 7500$ per year \\
\hline
\end{tabular}




\section{Appendix 5}

Table 5: Relative importance of attributes

\begin{tabular}{|l|l|l|l|l|l|}
\cline { 5 - 6 } \multicolumn{2}{c|}{} & \multicolumn{2}{c}{ Importance (\%) } & \multicolumn{2}{l|}{$\begin{array}{l}\text { Utility (zero centred } \\
\text { differences) }\end{array}$} \\
\hline & W1 $\mathrm{n}=400$ & W2 $\mathrm{n}=\mathbf{2 7 2}$ & & W1 $\mathrm{n}=400$ & W2 $\mathrm{n}=\mathbf{2 7 2}$ \\
\hline Course reputation & 31.2 & 31.2 & low & -106 & -107 \\
\hline & & & average & 25 & 26 \\
\hline & & & high & 81 & 81 \\
\hline
\end{tabular}

\begin{tabular}{|l|l|l|l|l|l|}
\hline $\begin{array}{l}\text { University } \\
\text { reputation }\end{array}$ & 27.8 & 26.2 & low & -99 & -87 \\
\hline & & & average & 32 & 18 \\
\hline & & & high & 68 & 70 \\
\hline
\end{tabular}

\begin{tabular}{|l|l|l|l|l|l|}
\hline Orientation & 16.7 & 16.6 & $\begin{array}{l}\text { industry } \\
\text { focussed }\end{array}$ & -23 & -15 \\
\hline & & & $\begin{array}{l}\text { research } \\
\text { focussed }\end{array}$ & 5 & 2 \\
\hline & & & $\begin{array}{l}\text { teaching } \\
\text { focussed }\end{array}$ & 18 & 12 \\
\hline
\end{tabular}

\begin{tabular}{|l|l|l|l|l|l|}
\hline Distance & 10.1 & 9.3 & not local & -7 & -5 \\
\hline & & & local & 7 & 5 \\
\hline
\end{tabular}

\begin{tabular}{|l|l|l|l|l|l|}
\hline Fees & 9.5 & 3.7 & low & 24 & 8 \\
\hline & & & average & 9 & 6 \\
\hline & & & high & -33 & -14 \\
\hline
\end{tabular}

\begin{tabular}{|l|l|l|l|l|l|}
\hline $\begin{array}{l}\text { Entry } \\
\text { qualifications }\end{array}$ & 4.8 & 13.0 & low & 10 & -13 \\
\hline & & & average & 9 & 24 \\
\hline & & & high & -19 & -11 \\
\hline & 100 & 100 & \multicolumn{2}{|l}{} \\
\cline { 2 - 4 } & &
\end{tabular}


Appendix 6 Figure 1: Importances. Wave One (left hand side) and Wave Two (right hand side)
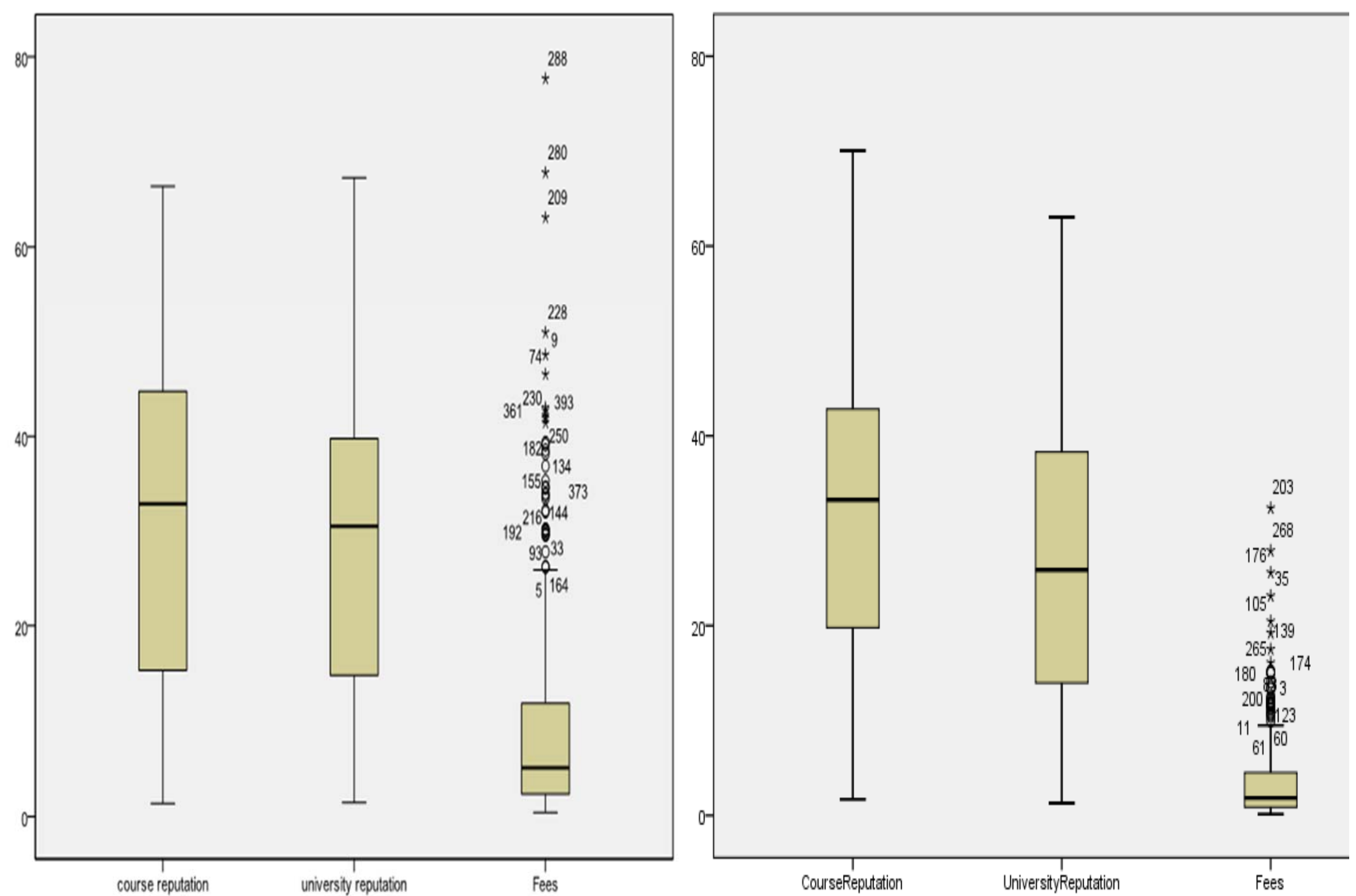


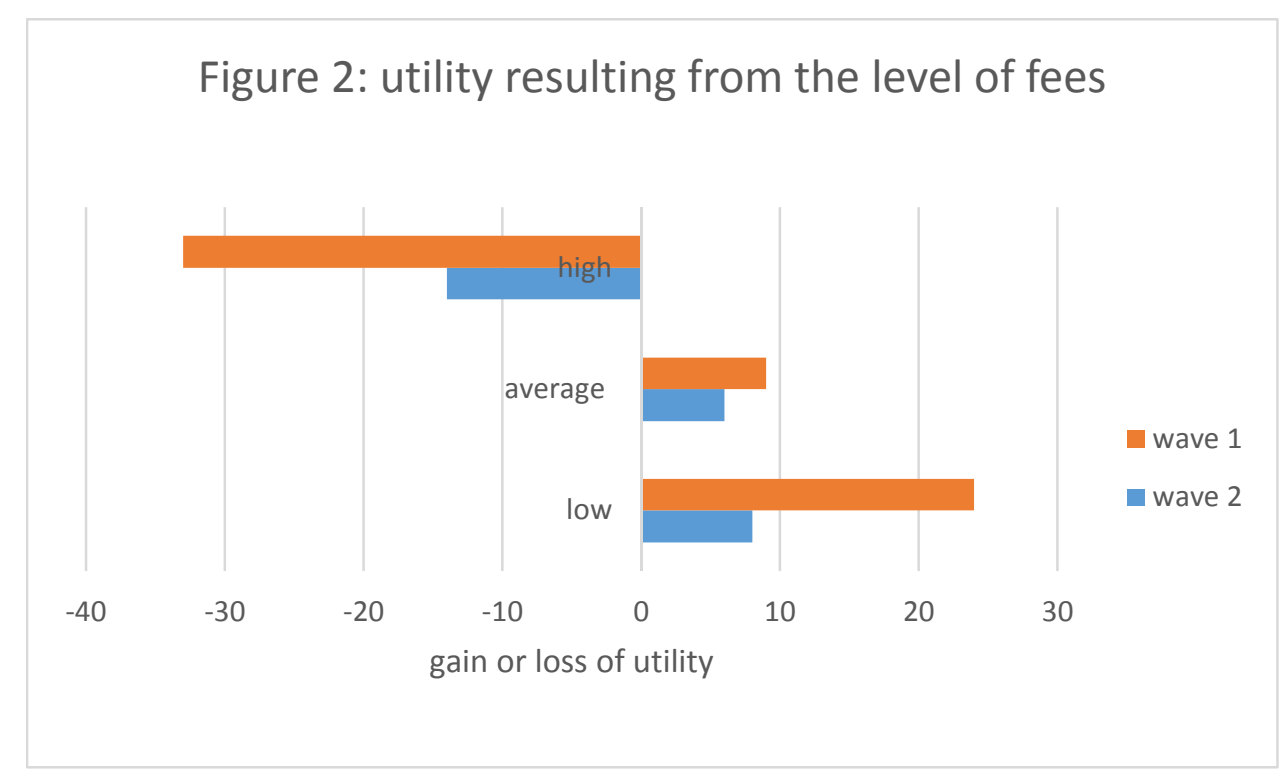

Appendix 8

Figure 3: utility resulting from the level of entry qualifications
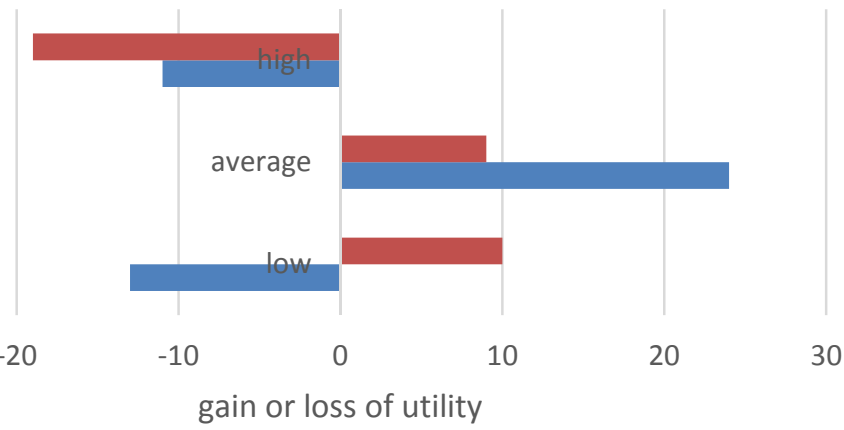

wave 1

a wave 2 


\section{Appendix 9}

Table 6: Comparison of ZCDs by 'whether parents went to university'

Zero Centred

Differences in utility

(ZCDs)

\begin{tabular}{|l|l|l|l|l|l|l|l|}
\cline { 3 - 8 } \multicolumn{2}{c|}{} & $\begin{array}{l}\text { Wave } \\
\text { One } \\
178 / 400\end{array}$ & $\begin{array}{l}\text { Wave } \\
\text { Two } \\
121 / 272\end{array}$ & $\begin{array}{l}\text { Wave One } \\
222 / 400\end{array}$ & $\begin{array}{l}\text { Wave Two } \\
151 / 272\end{array}$ & W1 & W2 \\
\hline Course reputation & low & -111 & -112 & -102 & -102 & $* * *$ & - \\
\hline & average & 22 & 26 & 27 & 26 & $*$ & - \\
\hline & high & 87 & 86 & 75 & 77 & - & - \\
\hline
\end{tabular}

\begin{tabular}{|l|l|l|l|l|l|l|l|}
\hline University reputation & low & -102 & -99 & -95 & -78 & $*$ & $* * *$ \\
\hline & average & 32 & 22 & 31 & 15 & - & $*$ \\
\hline & high & 72 & 77 & 64 & 63 & - & $* * *$ \\
\hline
\end{tabular}

\begin{tabular}{|l|l|l|l|l|l|l|l|}
\hline Orientation & $\begin{array}{l}\text { industry } \\
\text { focused }\end{array}$ & -23 & -13 & -23 & -15 & - & - \\
\hline & $\begin{array}{l}\text { research } \\
\text { focused }\end{array}$ & 7 & -4 & 3 & 7 & - & - \\
\hline & $\begin{array}{l}\text { teaching } \\
\text { focused }\end{array}$ & 16 & 17 & 20 & 8 & - & - \\
\hline
\end{tabular}

\begin{tabular}{|l|l|l|l|l|l|l|l|}
\hline Distance & not local & -5 & -2 & -9 & -7 & - & - \\
\hline & local & 5 & 2 & 9 & 7 & - & - \\
\hline
\end{tabular}

\begin{tabular}{|l|l|l|l|l|l|l|l|}
\hline Fees & low & 20 & 8 & 27 & 9 & $* *$ & - \\
\hline & average & 7 & 5 & 10 & 6 & - & - \\
\hline & high & -27 & -12 & -37 & -15 & $* *$ & - \\
\hline
\end{tabular}

\begin{tabular}{|l|l|l|l|l|l|l|l|}
\hline Entry qualifications & low & 7 & -18 & 12 & -9 & $* *$ & - \\
\hline & average & 6 & 20 & 11 & 28 & $* *$ & $*$ \\
\hline & high & -13 & -2 & -24 & -19 & $* *$ & $* *$ \\
\hline
\end{tabular}

Asterisks indicate a significant difference between respondents whose parents went to university and those who didn't.

$\mathrm{p}<0.05=* \quad \mathrm{p}<0.01=* * \quad \mathrm{p}<0.005=* * *$ 


\section{Appendix 10}

Figure 4: Parental influence on attitude to university reputation

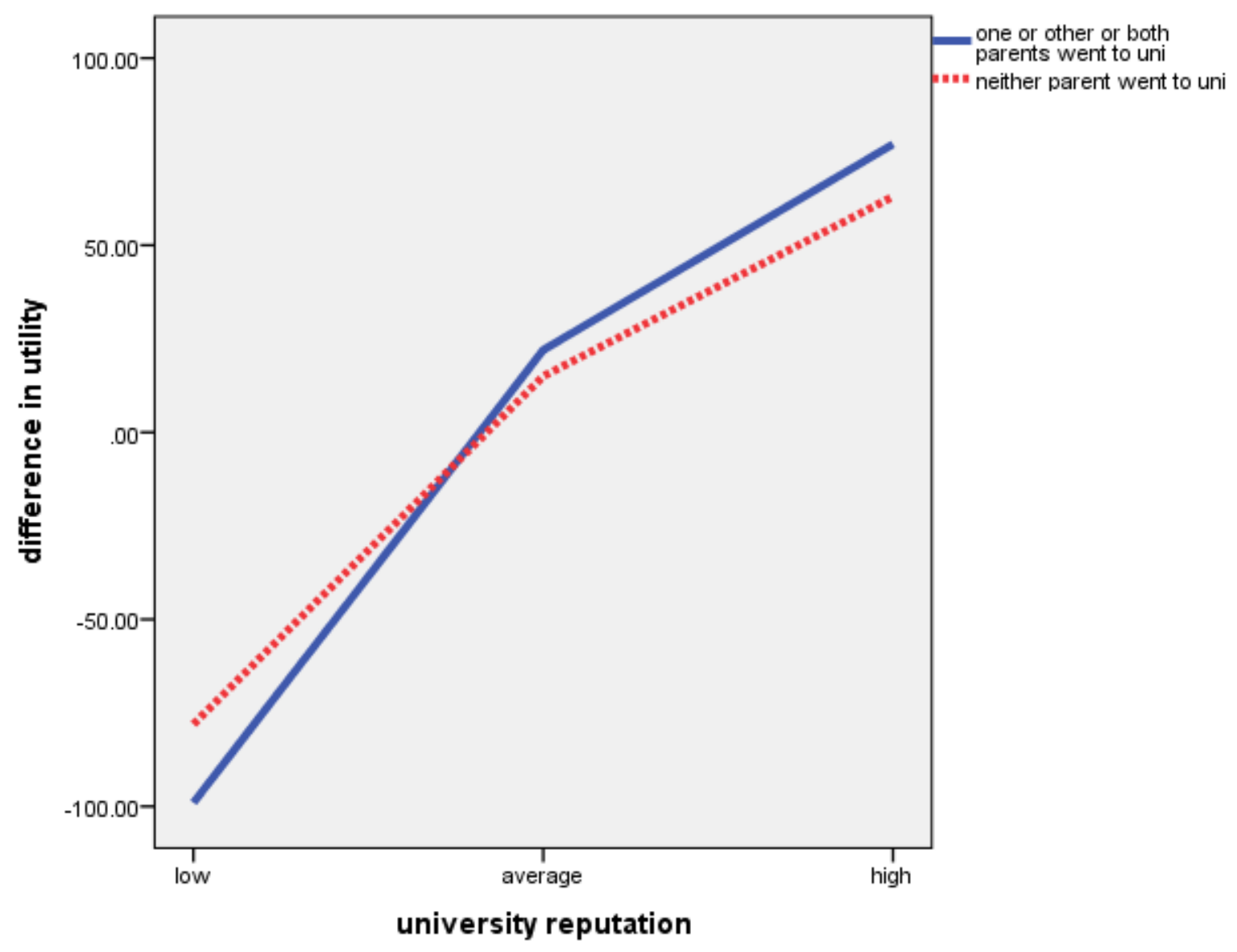




\section{Appendix 11}

Table 7: Social class comparisons

Zero Centred

Differences in utility

(ZCDs)

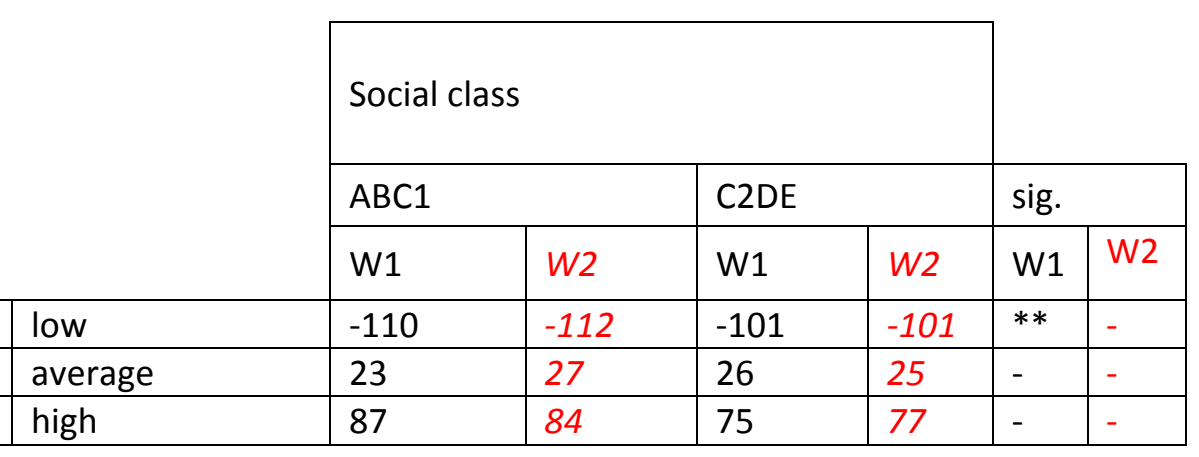

\begin{tabular}{|l|l|l|l|l|l|l|l|}
\hline University reputation & low & -106 & -95 & -92 & -80 & $* * *$ & $*$ \\
\hline & average & 33 & 19 & 31 & 16 & - & - \\
\hline & high & 74 & 75 & 61 & 64 & $* * *$ & $*$ \\
\hline
\end{tabular}

\begin{tabular}{|l|l|l|l|l|l|l|l|}
\hline Orientation & industry focused & -22 & -17 & -24 & -12 & - & - \\
\hline & research focused & 7 & 0 & 2 & 5 & - & - \\
\hline & teaching focused & 15 & 17 & 21 & 7 & - & - \\
\hline
\end{tabular}

\begin{tabular}{|l|l|l|l|l|l|l|l|}
\hline Distance & not local & -2 & 0 & -13 & -10 & $*$ & $*$ \\
\hline & local & 2 & 0 & 13 & 10 & $*$ & $*$ \\
\hline
\end{tabular}

\begin{tabular}{|l|l|l|l|l|l|l|l|}
\hline Fees & low & 21 & 6 & 27 & 10 & - & $* *$ \\
\hline & average & 8 & 4 & 9 & 7 & - & $* *$ \\
\hline & high & -29 & -10 & -36 & -17 & - & $* *$ \\
\hline
\end{tabular}

\begin{tabular}{|l|l|l|l|l|l|l|l|}
\hline Entry qualifications & low & 9 & -14 & 11 & -11 & - & - \\
\hline & average & 8 & 22 & 10 & 26 & - & - \\
\hline & high & -17 & -8 & -21 & -15 & - & - \\
\hline
\end{tabular}

Asterisks indicate a significant difference between $A B C 1$ s and C2DEs

$\mathrm{p}<0.05=^{*} \quad \mathrm{p}<0.01=* * \quad \mathrm{p}<0.005=* * *$ 


\section{Appendix 12}

Table 8: Gender effects on attribute utility

\begin{tabular}{|c|c|c|c|c|c|c|c|}
\hline \multicolumn{2}{|l|}{$\begin{array}{l}\text { Zero Centred } \\
\text { Differences in utility } \\
\text { (ZCDs) }\end{array}$} & \multicolumn{2}{|c|}{ Male } & \multicolumn{2}{|c|}{ Female } & \multicolumn{2}{|l|}{ sig. } \\
\hline & & \multirow{2}{*}{$\begin{array}{c}W 1 \\
-103\end{array}$} & \multirow{2}{*}{$\begin{array}{l}W 2 \\
-107\end{array}$} & \multirow{2}{*}{$\begin{array}{l}\text { W1 } \\
-108\end{array}$} & \multirow{2}{*}{$\begin{array}{l}W 2 \\
-106\end{array}$} & \multirow{2}{*}{$\begin{array}{l}\text { W1 } \\
\end{array}$} & \multirow{2}{*}{$\begin{array}{l}W 2 \\
-\end{array}$} \\
\hline Course reputation & low & & & & & & \\
\hline & average & 22 & 27 & 27 & 25 & $*$ & - \\
\hline & high & 81 & 80 & -81 & 81 & - & - \\
\hline \multirow[t]{3}{*}{ University reputation } & low & -103 & -88 & -95 & -87 & $*$ & - \\
\hline & average & 32 & 17 & 32 & 18 & - & - \\
\hline & high & 72 & 71 & 63 & 68 & - & - \\
\hline \multirow{3}{*}{ Orientation } & industry focused & -11 & -12 & -34 & -16 & $* * *$ & - \\
\hline & research focused & 0 & 3 & 9 & 2 & - & - \\
\hline & teaching focused & 11 & 9 & 25 & 14 & $*$ & - \\
\hline \multirow[t]{2}{*}{ Distance } & not local & -3 & -7 & -12 & -3 & $*$ & - \\
\hline & local & 3 & 7 & 12 & 3 & $*$ & - \\
\hline \multirow[t]{3}{*}{ Fees } & low & 25 & 7 & 23 & 9 & - & - \\
\hline & average & 7 & 5 & 11 & 6 & $*$ & - \\
\hline & high & -32 & -12 & -32 & -15 & - & - \\
\hline \multirow[t]{3}{*}{ Entry qualifications } & low & 10 & -6 & 10 & -18 & - & * \\
\hline & average & 9 & 20 & 9 & 28 & - & $*$ \\
\hline & high & -19 & -13 & -19 & -10 & - & - \\
\hline
\end{tabular}

Asterisks indicate a significant difference between male and female

$\mathrm{p}<0.05=* \quad \mathrm{p}<0.01=* * \quad \mathrm{p}<0.005=$ 


\section{References}

Ajzen, I. and M. Fishbein (1980). Understanding attitudes and predicting social behavior. Englewood Cliffs NJ, Prentice-Hall.

Allen, D. E. (2002). "Toward a Theory of Consumer Choice as Socio-historically Shaped Practical Experience: The Fits-Like-a-Glove (FLAG) Framework." Journal of Consumer Research 28(March): 515-532.

Bergerson, A. (2009). " Special Issue: College Choice and Access to College: Moving Policy, Research, and Practice to the 21st Century." 354.

Bettman, J. R., M. F. Luce, et al. (1998). "Constructive Consumer Choice Processes." " Journal of Consumer Research 25(December): 187-217.

Briggs, S. and A. Wilson (2007). "Which university? A study of the influence of cost and information factors on Scottish undergraduate choice." Journal of Higher Education Policy and Management 29(1): 57-72.

Brooks, R. (2002). "Edinburgh, Exeter, East London - or employment? A review of research on young people's higher education choices." Educational Research 44(2): 217-227.

Chapman, R. G. (1986). "Toward a Theory of College Selection: a Model of College Search and Choice Behavior." Advances in Consumer Research 13: 246-250.

Chapman, R. G. (1993). "Non simultaneous relative performance analysis: Meta-analysis from 80 college-choice surveys with 55,276 respondents " Journal of Marketing for Higher Education 4(1/2): 405-422.

Clarke, M. (2007). "The Impact of Higher Education Rankings on Student Access, Choice, and Opportunity." Higher Education in Europe 32(1): 59-70.

Coccari, R. and R. Javalgi (1995). "Analysis of students' needs in selecting a college or university in a changing environment." Journal of Marketing for Higher Education 6(2): 27-39.

Cubillo, J. M., J. Sanchez, et al. (2006). "International students' decision-making process." International Journal of Educational Management. 20(2): 101-115.

Donnellan, J. (2002). The impact of marketer controlled factors on college-choice decisions by students at a public research university (dissertation) Dissertation, University of Massachusetts.

Doolan, K. (2010). "Weight of Costs-The Financial Aspects of Student Course Choices and Study Experiences in a Croatian Higher Education Setting." Revija za socijalnu politiku 17(2).

Dunnett, A., J. Moorhouse, et al. (2012). "Choosing a university: A conjoint analysis of the impact of higher fees on students applying for university in 2012." Tertiary Education and Management. 18(3): 199-220.

Foskett, N. H. and J. Hemsley-Brown (2001). Choosing futures: young people's decision-making in education, training and careers markets, Routledge.

Hauser. (n.d.). "Note on Conjoint Analysis." from http://www.mit.edu/ hauser/Papers/NoteonConjointAnalysis.pdf.

Hawdon, C. (2012). Tracking the Decision-making of High Achieving Higher Education Applicants, UCAS Report on behalf of The Department for Business Innovation and Skills and the Sutton Trust.

HESA. (2011). "Higher Education Statistics Agency." Retrieved October 25 2011, from http://www.hesa.ac.uk/index. php?option=com content\&task=view\&id=1897\&ltemid=239.

Holdswoth, D. and D. Nind (2005). "Choice modelling New Zealand high school seniors' preferences for university education " Journal of Marketing for Higher Education 15(2): 81-104.

Hooley, G. J. and J. E. Lynch (1981). "Modelling the student university choice process through the use of conjoint measurement techniques." European Research 9: 158-170.

Hossler, D. and K. S. Gallagher (1987). "Studying student college choice: A three-phase model and the implications for policy makers " College and University 62(3): 207-221. 
Ivy, J. (2006). "Higher education institution image: A correspondence analysis approach." International Journal of Educational Management 15(6/7): 276-282.

James, R. (2000). "Non-Traditional Students in Australian Higher Education: Persistent Inequities and the New Ideology of 'Student Choice "Tertiary Education and Management. 6(2): 105-117.

Kallio, R. (1995). "Factors influencing the college choice decisions of graduate students." Research in Higher Education 36(1): 109-125.

Levine, D. P. (1998). Subjectivity in Political Economy: Essays on wanting and choosing. London, Routledge.

Lin, L. (1997). "What are student education and educational related needs? ." Marketing and Research Today 25(3): 199-212.

Maringe, F. (2006). "University and course choice: Implications for positioning, recruitment and marketing." International journal of educational management 20(6): 466-479.

Mitra, K., M. C. Reiss, et al. (1999). "An examination of perceived risk, information search and behavioral intentions in search, experience and credence services." Journal of Services Marketing 13(3): 208-228.

Molesworth, M., R. Scullion, et al., Eds. (2011). Marketisation of higher education and the student consumer. Abingdon, Routledge.

Moogan, Y. J. (2011). "Can a higher education institution's marketing strategy improve the studentinstitution match?" International journal of educational management 25(6): 570 - 589.

Morgan, S. L. (2002). "Modeling preparatory commitment and non-repeatable decisions: Information processing, preference formation, and educational attainment." Rationality and Society 14(4): 387 - 429.

Murphy, P. (1981). "Consumer buying roles in college choice: Parents' and students' perceptions." College and University 56(2): 140-150.

OpinionPanel. (2013). "The Opinion Panel Community." Retrieved 710 2013, 2013, from http://www.opinionpanel.co.uk/.

Pasternak, R. (2005). "Choice of institutions of higher education and academic expectations: the impact of cost-benefit factors "Teaching in Higher Education 10(2): 189/201.

Paulsen, M. B. (1990). College Choice: Understanding Student Enrollment Behaviour. ASHEERIC Higher Education Report. Washington D. C., School of Education and Human Development, The George Washington University. No 6.

Perna, L. W. (2006). "Understanding the relationship between information about college prices and financial aid and students' college-related behaviors." American Behavioral Scientist 49(12): 1620-1635.

Pitre, P. E., T. Johnson, et al. ( 2006). "Understanding predisposition in college choice: Toward an integrated model of college choice and Theory of Reasoned Action." College and University Journal 81(2): 35 - 42.

Price, L., F. Matzdorf, et al. (2003). "The impact of facilities on student choice of university. ." Facilities 21 (10): 212-222.

Qureshi, S. (1995). "College accession research: New variables in an old equation." Journal of Professional Services Marketing 12(2): 163-170.

Raposo, M. and H. Alves (2007) "A model of university choice: an exploratory approach." Munich Personal RePEc Archive (MPRA)

Robertson, C., Ed. (1996). The Wordsworth Dictionary of Quotations Hertfordshire, Wordsworth Editions Ltd.

Shanka, T., V. Quintal, et al. (2005). "Factors influencing international students' choice of an education destination - a correspondence analysis." Journal of Marketing for Higher Education 15(2): 31-46.

Shostack, G. L. (1987). "Service Positioning through Structural Change." Journal of Marketing 51(1): 34-43. 
Soutar, G. N. and J. P. Turner (2002). "Students' preferences for university: a conjoint analysis." International journal of educational management 16(1): 40-45.

Tierney, W. G. and K. M. Venegas (2009). "Finding money in the table: Information, financial aid and access to college "The Journal of Higher Education 80(4): $363-368$.

Turner, J. P. (1998). An investigation of business undergraduates' choice to study at Edith Cowan University (unpublished research report), Edith Cowan University, Perth.

Webb, M. (1993). "Variables influencing graduate business students' college selections." College and University Feature (Fall 1992/Winter 1993): 38-46.

Yamamoto, G. T. (2006). "University evaluation-selection: A Turkish case " International Journal of Educational Management 20(7): 559-569.

Zaichkowsky, J. L. (1985). "Measuring the Involvement Construct " Journal of Consumer Research 12(December): 341-352.

Zeithaml, V. A. (1981). How consumer evaluation processes differ between goods and services. The Marketing of Services J. Donnelly and W. George. Chicago, AMA.

Zeithaml, V. A., A. Parasuraman, et al. (1985). "Problems and Strategies in Services Marketing." Journal of Marketing 49(2): 33-46. 